\title{
ÉPITŐIPAR 4.0
}

\section{CONSTRUCTION 4.0}

\author{
Nagy Orsolya ${ }^{1}$, Szabó Zs. Roland ${ }^{2}$ \\ 1kutató, Budapesti Corvinus Egyetem Stratégiai és Nemzetközi Menedzsment Kutatóközpont, Budapest \\ orsolya.nagy3@stud.uni-corvinus.hu \\ ${ }^{2} \mathrm{PhD}$, habilitált egyetemi docens, Budapesti Corvinus Egyetem Stratégiai és Nemzetközi Menedzsment Kutatóközpont, Budapest \\ zsoltroland.szabo@uni-corvinus.hu
}

\section{ÖSSZEFOGLALÁS}

A digitális transzformáció az építőipart is elérte. Az Építőipar 4.0-nak sajátossága az Ipar 4.0-val szemben, hogy lényegesen több benne az egyediség. Az Építőipar 4.0 egy szemléletváltás, mely lényegesen szorosabb együttmúködésre épül a teljes ellátási és értékláncban, melyet digitális platform(ok)on keresztül digitális technológiák támogatnak. A digitalizáció jelentősen csökkentheti az átfutási időt, a költségeket és a környezeti terhelést is, azonban kiteljesedésének még jelentős keresleti és kínálati korlátai vannak.

\section{ABSTRACT}

The digital transformation has reached the construction industry. The special feature of Construction 4.0 compared to Industry 4.0 is that there is significantly more uniqueness in it. Construction 4.0 is a change of approach that requires significantly closer collaboration across the entire supply and value chain supported by digital technologies on platform(s). Digitalization can significantly reduce lead times, costs and environmental impacts, but there are still significant supply and demand constraints.

Kulcsszavak: digitalizáció, IKT, transzformáció, építőipar, platform

Keywords: digitalization, ICT, transformation, construction, platform

\section{BEVEZETÉS}

A digitális technológiák és az Ipar 4.0 fejlődése elindította az építőiparban is a digitális transzformációt. A digitális transzformáció a teljes iparági értékláncot érinti, és a jelenlegi gyakorlathoz képest lényegesen hatékonyabb és eredményesebb vállalati múködést hoz magával. Ez megjelenik mind a költségek, mind az 
átfutási idő, mind a környezeti terhelés csökkenésében. Jelenleg azonban, a digitális transzformáció lassan zajlik az építöiparban, az okainak feltárása alapos tudományos vizsgálatokat követel meg. Kérdés továbbá, hogy a jelenleg kialakult pandémiahelyzet mennyire fogja elösegíteni vagy felgyorsítani a digitális transzformációt az építőiparban.

\section{AZ ÉPÍTŐIPAR 4.0 ÉS AZ IPAR 4.0}

Napjainkban limitált szakirodalom áll rendelkezésre arra vonatkozóan, hogy pontosan mit is foglal magában az „Építőipar 4.0”. Thuy Duong Oesterreich és Frank Teuteberg 2016-ban már rámutattak arra, hogy hogyan is lehetne alkalmazni az építöiparban az Ipar 4.0-t. Álláspontjuk szerint az épületinformációs modellezés (Building Information Modelling, BIM) teremtette meg annak az alapjait, hogy az építöiparban ténylegesen megkezdődhessen a negyedik ipari forradalom. Azonban az Építöipar 4.0-ra mint fogalomra még nem született egységes definíció.

Az Ipar 4.0 esetében viszonylag standardizált folyamatok támogatása történik digitális eszközökkel. Azonban az ipari termeléssel szemben külön problémát jelent, hogy az építőipari projektek típusa, helye, mérete, a részt vevő vállalkozások minden egyes beruházása esetén változik, ezért a folyamatok standardizálása külön kihívás a modern technológia hiánya és a szakképzetlen munkaerő mellett. A vállalkozások és a vállalatvezetők számára nem világos, hogy az ipari forradalom milyen modern technológiákat és eszközöket nyújt.

Az Építőipar 4.0 egy teljesen új szemléletet jelent, amely magában foglalja a teljes ellátási és értékláncot. A teljes értékláncban vállalkozások sokasága müködik együtt, miközben az együttmüködést digitális platform(ok)on kommunikáló technológiák támogatják. Az Építöipar 4.0 nem korlátozódik a tervezésre és a kivitelezésre, hanem kiterjed az épületüzemeltetésre és az épületek utóéletének menedzselésére is.

\section{A DIGITALIZÁLT ÉPITTŐIPARI ÉRTÉKLÁNC}

A BIM-technológia megjelenése megteremtette a lehetőséget arra, hogy a hagyományos építöipari értéklánc - mint a tervezés, a kivitelezés és az üzemeltetés egy platformra szervezve induljon meg a digitális transzformáció irányába. Ehhez kapcsolódhat az épületek átalakítása vagy éppen bontása, illetve az intelligens/ okos városok (Smart City) esetén az üzemeltetés kibővül az emberek változó igényeire is reflektálni képes épített környezet optimalizálásával és integrációjával (Center for Digital Built Britain, 2018). 
A tervezésben olyan elemek kapnak szerepet, mint a 3D-elemtárak, a minöségellenőrzés, a költségbecslés, az átlátható tervezés, a vizuális megjelenítés, az ütközésvizsgálat, a közös adatkezelési felület (Common Data Environment, CDE) és a fenntartható fejlödést szolgáló környezetbarát megoldások.

A kivitelezés és megvalósítás során az innovatív gyártási megoldások és a kibővült logisztika mellett kiemelt szerepet kapnak az integrált BIM-megoldások, a rendszerezett adatok, a részfolyamatokat összekapcsoló mobilalkalmazások, a hibalistát könnyítő technológiák, a projektek korai fázisába bevont innovatív megoldások (melyek kifejezetten támogatják a lean építkezési folyamatot), továbbá a 4D-tervezés, mely ütemezési szcenáriókkal támogatja a projekteket.

Külön szerepet kap a megfelelő adatáramlás a projektfázisok között (WhyteLobo, 2010), mely elősegíti, hogy az épületüzemeltetési munkák tervezhetőek és nyomon követhetőek, valamint biztonságosan kivitelezhetőek legyenek. Ezekkel a témákkal részletesen Xinghua Gao és Pardis Pishdad-Bozorgi (2019) foglalkozott.

Nagyobb hangsúlyt kap az épületek felújitása, átépitése és bontása is. Az új környezetbarát technológiák megjelennek az újrahasznosításban, az életciklus-analízisben, a bontási folyamatokban és a pontfelhőből készült BIM-modellekben is.

Az okosvárosok kialakításához szükséges integráció magában foglalja többek között azt is, hogy hogyan javíthatja az épített környezet a városlakók életminőségét, és ezeket az információkat hogyan lehet alkalmazni gazdasági és társadalmi infrastruktúrák megtervezéséhez és felépítéséhez (Whyte, 2019). Kiemelt értéket teremtenek azok a technológiák és szolgáltatások, amelyek a tervezés fázisától az integrációig kapcsolják össze az adatáramlást. A növekvő adatmennyiség és az adatmenedzsment elősegíti, hogy humán központú infrastrukturális megoldások születhessenek, melyek a társadalom és a környezet számára is fontos tényezők (Engin et al., 2019). Mindezek mellett a negyedik ipari forradalom a meglévő eszközök digitalizációjával is számos értéket teremt.

Projekt, vállalat és technológiagyártó szintjén is nem kevés kihívásnak néz elébe ez a jelentősen szegmentált piac. A piaci szereplők a mostaninál jóval szorosabb együttműködésre fognak kényszerülni. Közösen kell olyan projektszintü döntéseket meghozniuk, amelyek több vállalkozás számára magasfokú változásmenedzsmentet követelnek meg. A döntéseket olyan gazdasági és stratégiai eszközökkel kell támogatni, amelyek bizonyítják a technológiai átállás hatékonyságát, és irányt mutatnak arra vonatkozóan, hogy hogyan lehet értéket teremtve megfelelö technológiákat implementálni a vállalkozásokba. Az értékteremtéshez az innovatív vállalati kultúra mellett fontos szerepet kap a megfelelö informatikai tudással rendelkező közép- és felsővezetői réteg és a szakképzett munkaerő is. Számos multinacionális óriáscég mutatta már meg, hogy a megfelelő technológiai tudással rendelkező vállalkozások piaci értéke lényegesen magasabb versenytársaikénál, és egy munkavállaló lényegesen nagyobb értéket tud ezekben a vállalatokban teremteni (Makridakis, 2017). 


\section{TECHNOLÓGIÁK ÉS AZ ÉRTÉKLÁNC KAPCSOLATA}

Az építöipar lassan átalakul a Dolgok Internete (Internet of Things - IoT) ökoszisztéma irányába. A technológiák összekapcsolódásával az építőiparban megszületik a digitális technológiák piaca, de a technológiai határok már most is szemmel láthatóan elmosódnak, ezért a piaci szegmentálást nehéz elöre megjósolni. Az eddigi megfigyeléseim alapján jelenleg négy különböző kutatási ágba lehet csoportosítani a technológiákat. A piacon megjelenő különféle szoftverplatformok mellett a szakmaspecifikus, ember-számítógép interakcióját elősegítő megoldások, a digitális és fizikai integrációt segítő technológiai réteg és a kapcsolódó szenzorok és eszközök.

A digitális transzformáció központi eleme a szoftverplatform, melynek fö eleme a BIM-modell. A felhőalapú együttmüködés és a BIM kombinációja megteremti a lehetőséget arra, hogy további technológiák kapcsolódjanak a rendszerhez. A rendszer elemei adatkezelési platformot alkotnak a projekt teljes életciklusa alatt. A projektfázisok és szereplők között az adatok áramlását az Industry Foundation Classes (IFC) adatmodell biztosítja (Davtalab et al., 2018). Ez a platform közös adatkezelési környezetként (CDE) is müködik, mely biztosítja a projekt szereplöinek együttmüködését. Ali Ghaffarianhoseini és szerzőtársai 2017-ben rámutattak arra, hogy egy integrált CDE növeli a projektszereplők egyéni felelősségtudatát, melynek hatására nő a folyamatok hatékonysága, ezáltal csökken a teljes projekt költsége (Ghaffarianhoseini, 2017a). A projektszinten integrált CDE jelentősen redukálja a tervezési időt (Bryde et al., 2013), de egy megfelelő integrációhoz szükséges az is, hogy a jelenlegi üzleti modelleken képesek legyenek változtatni a piaci szereplők. Az implementálás során ügyelni kell arra is, hogy a nem egyértelmüen kiosztott szerepek és felelősségek az ellátási láncban a bizalom hiányához vezethetnek, ami nem várt költség, és logisztikai problémaként is jelentkezhet a későbbiekben.

Az ember és számitógép interakciója megteremti a lehetőséget az emberek és a gépek közötti információáramlásra. Az interakció történhet hardvereszközökön, képfeldolgozáson vagy akár gesztusokon keresztül is. Az interakció alapvető eleme lehet egy weboldal, egy mobilalkalmazás vagy egy progresszív weboldal alkalmazás (PWA) is. A mobilalkalmazások és a helyszíni eszközök felhőmegoldásokkal kombinálva valós idejü projektkezelési problémákat oldanak meg, azonban az adatbiztonság számos mobilalkalmazást használó felhasználó számára kihívást is jelent (Conlin-Retik, 1997).

A digitális és fizikai integrációs réteg technológiái segítik az anyagok és tárgyak összekapcsolását a 3D virtuális és fizikai tér között, az ellátási lánc vagy a gyártási megoldások összekapcsolását. Ide tartozik a kiterjesztett és a virtuális valóság (Augmented \& Virtual Reality) (Ahmed, 2019; Bassanino et al., 2014), a 3D-nyomtatás és -kivetítés, valamint a megjelenő új építőanyagok is. Ezen technológiák jelentős része vizualizáción alapul. A vizualizáció megkönnyíti a komplex ötletek megbeszélését 
az érdekelt felek között (Ghaffarianhoseini et al., 2017a) és a távoli munkavégzést a 3D-térben. A Virtual Reality (VR) technológiák növelik a biztonság szerepét a tervezésben (Sacks et al., 2015), mivel elöre nem látható projektakadályokat képesek megjeleníteni, és ezzel azok már felmerülésük előtt kezelhetőkké válnak.

A kapcsolódó szenzorok és eszközök távoli és valós idejủ adatgyüjtést tesznek lehetővé. Ide tartoznak a kamerák (Konstantinou et al., 2019), a szenzorok és az intelligens címkék (RFID, BLE) továbbá a robotika és a drónok. Ezek a technológiák kiemelten segítik az olyan munkakörnyezetet, ahol különösen fontos a munkavédelem és a biztonság. A kameraalapú technológiák támogatják az erőforrás-tervezést, azonban számos országban jogi kérdések merülnek fel az alkalmazásukkal kapcsolatban. Az intelligens címkék a folyamatos nyomon követéssel növelik a munkabiztonságot és a hatékonyságot a projekteken. A virtuális szimulációk megakadályozzák a baleseteket, míg Juan Manuel Davila Delgado és szerzőtársai (2019) szerint a robotika és autonóm technológiák megjelenésével új munkavédelmi kérdések is felmerülnek. Ezen technológiák alkalmazása csökkenti a munkavédelem költségeit, és megkönnyíti a nehéz fizikai munkát.

A felsorolt technológiák kombinációja mellett a teljes építőipari értékláncban megjelenik a nagyadatok elemzése (Big Data Analytics), a gépi tanulás (machine learning) és a Blockchain-technológia is. A megjelenő technológiák nem csupán a vállalkozások hatékonyságát növelik, de a fenntartható fejlödést és a környezetvédelmet is támogatják (Carvajal-Arango et al., 2019; Lu-Lee, 2015; GhaffarianHoseini et al., 2017b).

\section{MIÉRT LASSÚ A DIGITÁLIS TRANSZFORMÁCIÓ AZ ÉPITŌIPARBAN?}

Több nézőpontból is lehet vizsgálni a kérdést, ezekből két jelentős gátat emelünk ki, először is, az építőipari vállalkozások nézőpontjából: szervezeti, stratégiai és technológiai kérdéseket figyelembe véve. Ez alapján komoly gátat jelent, hogy a vezetők és az alkalmazottak digitális tudásszintje alacsony, a szervezeti struktúrák merevek, a vállalatok közötti integráció alacsony szintü. A BIM elterjedése (hazánkban különösen) alacsony, és a BIM csak ritkán kerül kiterjesztésre a teljes értékláncra. A kezdeti (valamivel magasabb) befektetett munkát nem vállalják be a szereplők, mivel önmagukban az nem térül meg, azonban a teljes értékláncot tekintve jelentős megtakarítások lennének elérhetőek megfelelő hálózati együttmüködés esetén. E kapcsán gondot jelent a szereplök közötti bizalomhiány is.

Másodszor, a technológia gyártója vagy szolgáltatója szempontjából. Mennyire hajlandó a piac befogadni az új technológiát? Milyen gyorsan tud a technológiai szolgáltató növekedni a piacon? E tekintetben, számos új technológia jelenik meg, azonban ezekkel szemben nagy a bizonytalanság, illetve még kevés olyan referenciaprojekt van, mely a technológiák tényleges hatékonyságát alátámasztaná, 
vagy ezek a projektek jelentősen eltérnek az új megrendelő körülményeitől. Másfelől az új technológiai szolgáltatók többsége fiatal vállalkozás, melyek a nagyobb igényeket még nem tudják kiszolgálni.

Tehát összességében még sem a keresleti, sem a kínálati piac nem tekinthető érettnek, azonban az Ipar 4.0 fejlödésével egyre több szakember jelenik meg az építőiparban is, valamint kutatóhelyek és tanácsadók is segíthetik az Építőipar 4.0 kialakulását, amelyre Nagy-Britanniában nagyon jó példát láthatunk. Másfelöl most még a kínálati piac is fejletlen, de egyre több ígéretes technológia jelenik meg. A technológiák alkalmazása olyan hatékonyságjavulást hoz magával, mely az éles piaci versenyben egyre több vállalkozást kényszerít rá a digitális transzformációra.

\section{IRODALOM}

Ahmed, S. (2019): A Review on Using Opportunities of Augmented Reality and Virtual Reality in Construction Project Management. Organization, Technology and Management in Construction: An International Journal, 11, 1, 1839-1852. DOI: 10.2478/otmcj-2018-0012, https://content.sciendo.com/view/journals/otmcj/11/1/article-p1839.xml?language=en

Bassanino, M. - Fernando, T. - Wu, K. C. (2014): Can Virtual Workspaces Enhance Team Communication and Collaboration in Design Review Meetings? Architectural Engineering and Design Management, 10, 3-4, 200-217. DOI: 10.1080/17452007.2013.775102, https://bit.ly/35Cmm3u

Bryde, D. - Broquetas, M. - Volm, J. M. (2013): The Project Benefits of Building Information Modelling (BIM). International Journal of Project Management, 31, 7, 971-980. DOI: 10.1016/j.ijproman.2012.12.001, https://www.apm.org.uk/media/7571/building-information-modelling.pdf

Carvajal-Arango, D. - Bahamón-Jaramillo, S. - Aristizábal-Monsalve, P. et al. (2019): Relationships between Lean and Sustainable Construction: Positive Impacts of Lean Practices over Sustainability during Construction Phase. Journal of Cleaner Production, 234, 1322-1337. DOI: 10.1016/j.jclepro.2019.05.216

Center for Digital Built Britain (2018): Year One Report Towards a Digital Built Britain. University of Cambridge, https://www.cdbb.cam.ac.uk/news/2018CDBBYearlReport

Conlin, J. - Retik, A. (1997): The Applicability of Project Management Software and Advanced IT Techniques in Construction Delays Mitigation. International Journal of Project Management, 15, 2, 107-120. https://bit.ly/3nubFWV

Davila Delgado, J. M. - Oyedele, L. - Ajayi, A. et al. (2019): Robotics and Automated Systems in Construction: Understanding Industry-specific Challenges for Adoption. Journal of Building Engineering, 26, 1-15. DOI: 10.1016/j.jobe.2019.100868, https://www.researchgate.net/publication/334440069_Robotics_and_automated_systems_in_construction_Understanding_industry-specific_challenges_for_adoption

Davtalab, O. - Kazemian, A. - Khoshnevis, B. (2018): Perspectives on a BIM-integrated Software Platform for Robotic Construction through Contour Crafting. Automation in Construction, 89, 13-23. DOI: 10.1016/j.autcon.2018.01.006, https://www.researchgate.net/publication/322626918_ Perspectives_on_a_BIM-integrated_software_platform_for_robotic_construction_through_ Contour_Crafting

Engin, Z. - van Dijk, J. - Lan, T. et al. (2019): Data-driven Urban Management: Mapping the Landscape. Journal of Urban Management, 9, 2, 140-150. DOI: 10.1016/j.jum.2019.12.001, https://www.sciencedirect.com/science/article/pii/S2226585619301153?via\%3Dihub 
Gao, X. - Pishdad-Bozorgi, P. (2019): BIM-enabled Facilities Operation and Maintenance: A Review. Advanced Engineering Informatics, 39, 227-247. DOI: 10.1016/j.aei.2019.01.005, https:// www.researchgate.net/publication/330664165_BIM-enabled_facilities_operation_and_maintenance_A_review

Ghaffarianhoseini, A. - Tookey, J. - Ghaffarianhoseini, A. et al. (2017a): Building Information Modelling (BIM) Uptake: Clear Benefits, Understanding Its Implementation, Risks and Challenges. Renewable and Sustainable Energy Reviews, 75, 1046-1053. DOI: 10.1016/j. rser.2016.11.083, https://bit.ly/3nyMbHR

GhaffarianHoseini, A. - Zhang, T. - Nwadigo, O. et al. (2017b): Application of nD BIM Integrated Knowledge-based Building Management System (BIM-IKBMS) for Inspecting Post-construction Energy Efficiency. Renewable and Sustainable Energy Reviews, 72, 935-949. DOI: 10.1016/j.rser.2016.12.061, https://openrepository.aut.ac.nz/bitstream/handle/10292/10085/NZBERS-2014_proc_abs_GhaffarianHoseini-A.pdf?sequence $=2$ \&isAllowed $=\mathrm{y}$

Kache, F. - Seuring, S. (2017): Challenges and Opportunities of Digital Information at the Intersection of Big Data Analytics and Supply Chain Management. International Journal of Operations and Production Management, 37, 1, 10-36. DOI: 10.1108/IJOPM-02-2015-0078, https:// bit.ly/32PabPi

Konstantinou, E. - Lasenby, J. - Brilakis, I. (2019): Adaptive Computer Vision-based 2D Tracking of Workers in Complex Environments. Automation in Construction, 103, 168-184. DOI: 10.1016/j.autcon.2019.01.018, https://www.researchgate.net/publication/331333206_Adaptive_ computer_vision-based_2D_tracking_of_workers_in_complex_environments

Lu, Q. - Lee, S. (2015): An eeBIM-Based Platform Integrating Carbon Cost Evaluation for Sustainable Building Design. Computing in Civil Engineering, 371-378. DOI: 10.1061/ 9780784479247.046, https://bit.ly/3f5Y98Y

Makridakis, S. (2017): The Forthcoming Artificial Intelligence (AI) Revolution: Its Impact on Society and Firms. Futures, 90, 46-60. DOI: 10.1016/j.futures.2017.03.006, https://www.semanticscholar.org/paper/The-Forthcoming-Artificial-Intelligence-(AI)-Its-on-Makridakis/ 2c21a89a91e6920ab9ac9a40af05055b865d5666

Oesterreich, T. D. - Teuteberg, F. (2016): Understanding the Implications of Digitisation and Automation in the Context of Industry 4.0: A Triangulation Approach and Elements of a Research Agenda for the Construction Industry. Computers in Industry, 83, 121-139. DOI: 10.1016/j. compind.2016.09.006, https://bit.ly/2II7NCM

Perera, S. - Nanayakkara, S. - Rodrigo, M. N. N. et al. (2020): Blockchain Technology: Is It Hype or Real in the Construction Industry? Journal of Industrial Information Integration, 17, 100125. DOI: 10.1016/j.jii.2020.100125, https://www.sciencedirect.com/science/article/pii/ S2452414X20300017

Sacks, R. - Whyte, J. - Swissa, D. et al. (2015): Safety by Design: Dialogues between Designers and Builders Using Virtual Reality. Construction Management and Economics, 33, 1, 55-72. DOI: 10.1080/01446193.2015.1029504, http://centaur.reading.ac.uk/39658/8/01446193\%252E20 15\%252E1029504.pdf

Whyte, J. (2019): How Digital Information Transforms Project Delivery Models. Project Management Journal, 50, 2, 177-194. DOI: 10.1177/8756972818823304, https://journals.sagepub.com/ doi/full/10.1177/8756972818823304

Whyte, J. - Lobo, S. (2010): Coordination and Control in Project-based Work: Digital Objects and Infrastructures for Delivery. Construction Management and Economics, 28, 6, 557-567. DOI: 10.1080/01446193.2010.486838, https://www.researchgate.net/publication/227609813_Coordination_and_control_in_project-based_work_Digital_objects_and_infrastructures_for_delivery 